\section{Birlesik Dünya Arastrrma Global Journal of Business, BD-CENTER \\ Innovasyon ve Yayıneılık Merkezi \\ Economics and Management: \\ Current Issues}

Volume 9, Issue 3, (2019) 156-164
Global Journal of

Business,Economics and Management: Current Issues

\title{
Regional corruption variability in the European countries
}

Veronika Linhartova*, University of Pardubice, 53210 Pardubice, Czech Republic

\section{Suggested Citation:}

Linhartova, V. (2019). Regional corruption variability in the European countries. Global Journal of Business, Economics and Management: Current Issues. 9(3), 156-164. https://doi.org/10.18844/gibem.v9i3.4434

Received from August 27, 2019; revised from October 12, 2019; accepted from November 10, 2019.

Selection and peer review under responsibility of Prof.Dr. Cetin Bektas, Gaziosmanpasa University, Turkey.

${ }^{\circ} 2019$ United World Center of Research Innovation and Publication. All rights reserved.

\begin{abstract}
Quantification of the corruption rate in smaller sub-national areas is still a significantly unexplored area. Sub-national resolution of corruption rate could bring an entirely new dimension to the theory of causes and consequences of regional disparities. There are numerous reasons why to focus on this issue. Perhaps the strongest one is that if corruption negatively affects the economic performance, as many studies claim, the elimination of corruption in certain regions may be the key for the elimination of regional economic disparities and thus increase the economic performance of the state. Analysis of regional corruption may also lead to the creation of regional anti-corruption provisions that can bring a reduction of corruption rate at the national level. This context is formulated the main goal of this article. A new corruption quantification method reflecting inter-regional differences in the level of corruption in the European countries is designed. Using this method, it is possible to draw a comparison of individual NUTS II regions and identify those which are more affected by corruption than the others. A high level of corruption variability was confirmed for NUTS II regions, especially in Italy. Because of this variability, it could be very deceptive to evaluate the country as a whole from the corruption level viewpoint.
\end{abstract}

Keywords: Corruption, world bank, European union, economic performance, regional disparities, control of corruption.

\footnotetext{
* ADDRESS FOR CORRESPONDENCE: Veronika Linhartova, University of Pardubice, 53210 Pardubice, Czech Republic.
} 


\section{Introduction}

Despite the fact that corruption is not a new phenomenon and many authors have deal with this subject intensively for many years, there are still many questions that remain unanswered.

Even no unified definition of corruption concept exists either at the theoretical or practicalapplication level yet. Most of the existing approaches agree that corruption represents unfair practices with the goal of gaining a certain artificial advantage at the expense of others. Authors of this report build on the traditional definition according to Nye (1967) who describes corruption as 'behavior that deviates from the formal duties of a public role (elective or appointive) because of private regarding wealth or status gains'.

The question of quantification of corruption rate also invokes stormy discussions. Considering the fact that bribery and other forms of corruption are illegal in most countries, the people involved make every effort to carefully conceal their actions and revealing corruption is often almost impossible. Most of the existing studies have common that it focuses on the topic of corruption on the national level. Analysis of the regional corruption differences, causes and consequences is quite an unexplored territory worldwide. Only a few studies have been focused on quantifying the extent of corruption and its impact on the regional level (e.g., Del Monte and Papagni, 2007; Golden and Picci, 2005). Subnational resolution of corruption rate could bring a new dimension to the theory of causes and consequences of regional disparities.

The main aim of this article is formulated in this context. A new corruption quantification method reflecting inter-regional differences in the level of corruption in the European countries will be designed. Using this method, it will be possible to draw a comparison of individual NUTS II regions and identify those which are more affected by corruption than the others.

\section{Sub-national measurement of the level of corruption}

All indicators of corruption measurement focus on assessing corruption at the country level. According to the European Commission, the bureaucratic burden, particularly, and related fraudulent methods, of obtaining grants in the European countries represents an obstacle in drawing resources from European funds. These resources therefore paradoxically often do not help remove the undesirable regional disparities, but the distribution of these resources demonstrably increases the opportunities for corruption. This, in turn, brings to the region additional negative economic consequences, which may cause an increase in the disparities within the country as a whole. Cases of corruption dealing with the disbursement of funds are not exceptional even in other countries. Even so, due consideration is not given to corruption at the sub-national level.

\subsection{European quality of government index methodology}

Due to the absence of any method for determining corruption in a more or less affected subnational region, the next section will present a method for quantifying corruption at the sub-national level. The design of this method is based on the construction of the European Quality of Government Index developed by the European Commission together with The Quality of Government Institute.

The European index of Government Quality (EQI) was created for the purpose of quantification of quality of public government at the regional level. The index has so far been developed twice in 2010 and 2013. 27 EU Member States were included in the EQI in 2010. In 2013, 28 EU Member States are included as well as the Candidate States Turkey and Serbia in total 30 countries (European Commission, 2011, The Quality of Government Institute, 2013).

In addition to the national evaluation of the quality of governance, the resulting EQI also takes note of the evaluation of regional administration using regional data which the European Commission has drawn up for the needs of constructing the EQI. The EQI thus consists of two main parts: 
1. The first part of the EQI takes into account the national government level, which is represented by the Worldwide Governance Indicators (WGI) of the World Bank. Of the six pillars of the quality of governance, the European Commission chose four for the construction of the EQI: Voice and Accountability (GM1), Government Effectiveness (GM3), Rule of Law (GM5) Control of Corruption (CC) $(\mathrm{GM} 6)^{1}$ (European Commission, 2011; The Quality of Government Institute, 2013).

2. The second part of the EQI, which takes into account the regional level of governance, was compiled by the European Commission on the basis of a unique regional survey, conducted for the sole purpose of creating a Regional indicator of government quality, which would take into account regional aspects in the final construction of the EQI.

This unique research registered in the first construction of the EQI was executed in 172 NUTS II regions in 18 countries of the European Union in 2010 (from the remaining nine countries of the European Union only data at the national level were included). The research includes altogether 181 regional units. Data were obtained by means of surveying more than 33,000 inhabitants. The allEuropean regional research was conducted from 15th December 2009 to 1st February 2010 by means of telephone interviews with respondents older than 18 years and in the local language.

In the second construction of EQI, it was executed in 206 NUTS regions in 24 countries of the European Union in 2013 (from the remaining seven countries of the European Union only data at the national level were included). The research includes altogether 213 regional units. Data were obtained by means of research of more than 85,000 inhabitants.

The resulting regional quality of administration indicator reflects the actual experience of respondents with the use of individual public services, thus the quality of governance in the region is evaluated as it is perceived by its inhabitants; that is, the recipients of public administration. The regional indicator of government quality is composed of 16 separate indicators relating to the quality of administration in a particular region. These 16 indicators were developed based on 16 questions $^{2}$ developed in accordance with the pillars arising from the methodology of the WGI: Voice and Accountability, Government Effectiveness, Rule of Law and CC. In order to capture the most important sub-national differences, questions were focused on three public services that are often funded or administered at sub-national levels. Each of the four pillars mentioned thus involves issues relating to education, health care and law enforcement in the region. With a focus on these three services, respondents were asked to assess these public services with regard to the three fundamental concepts of quality administration - quality, impartiality and corruption. These three concepts are the pillars of the resulting regional indicator of quality government ${ }^{3}$.

A simple diagram of the formation of the Regional indicator of government quality is shown in Figure 1.

1 The resulting WGI value for the country is composed of a simple average of the four pillars. Thus each pillar contributes the same weight on the resulting value, i.e., $25 \%$.

2 The list of questions is available at http://www.qog.pol.gu.se/data/datadownloads/qogeuregionaldata/.

3 Data are aggregated three times using a simple average. First is the creation of the average values of responses to the questions. This will create 16 indicators for each region. Then these 16 values are aggregated into three defined pillars - quality, impartiality and corruption. Finally, these three pillars are aggregated into a single numerical regional quality of administration indicator. 


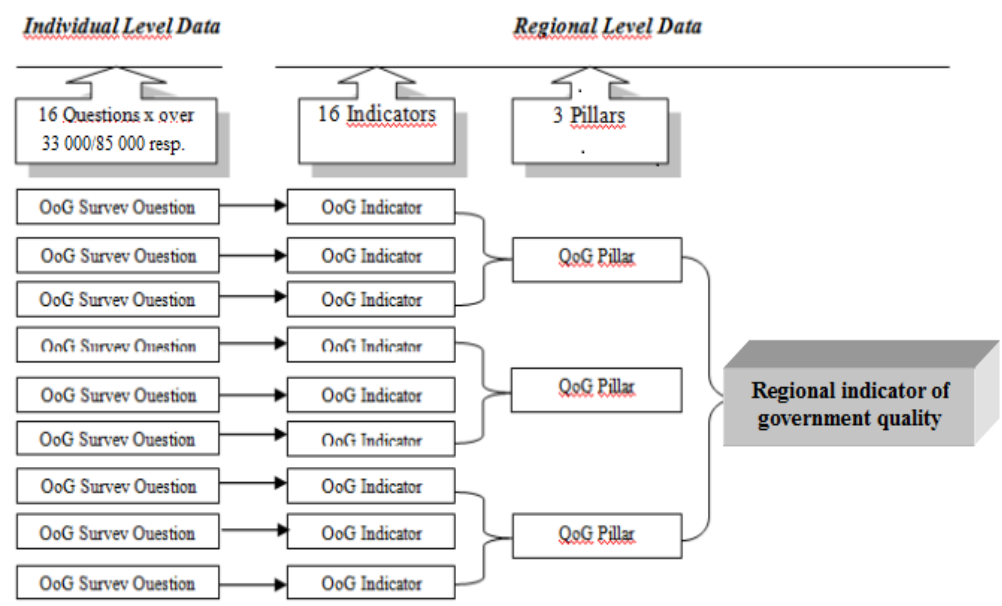

Figure 1. A regional indicator of government quality creation

The final index of government quality EQI upgrades in this way national evaluation of government quality created by the World Bank by regional extent. The final form of index construction is as follows:

$$
E Q I_{\text {regionXincountryy }}=W \mathrm{WI}_{\text {countryY }}+\left(\mathrm{R}_{\mathrm{qogregion} X i n c o u n t r y Y}-\mathrm{CR}_{\text {qogcountryY }}\right), \quad \text { where }
$$

$E Q I_{\text {regionxincountry }}$ is the final $E Q I$ in a region of a given country, $W G I_{\text {countryy }}$ is the national average of four above mentioned World Bank Governance Indicators for each country, $R_{\text {qogregionxincountry }}$ is the score from regional research, then regional indicator of government quality, $\mathrm{CR}_{\text {qogcountryy }}$ is the average of regional research of all regions of the country weighted by the proportion of population of each region per national population of the given country.

\subsection{Proposal of the regional index of corruption}

The above-mentioned methodology of EQI index construction is nowadays a unique approach which allows considering not only national but also regional extension when assessing the government quality. In context with the subject of our interest, the fact that the index EQI represents the approach which allows considering problems of regional corruption is determinative in this way. It is possible to change the composition of index EQI so that the final calculation reflects only the influence of corruption at the regional level.

Regarding equal balance of individual variable quantities entering the national index $\mathrm{WGI}_{\text {country }}$ and

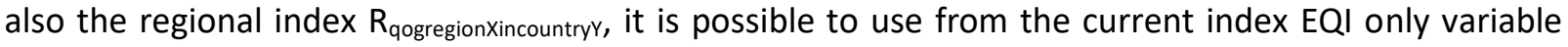
quantities related to the affection of a given territory by corruption by means of balance.

The final proposed regional index of corruption (RIC) would then be calculated based on the relation:

$$
\mathrm{RIC}_{\text {regionXincountry }}=\mathrm{CC}_{\text {country }}+\left(\mathrm{PC}_{\mathrm{qogregion} X i n c o u n t r y}-\mathrm{CPC}_{\text {qogcountryy }}\right), \quad \text { where }
$$

$\mathrm{RIC}_{\text {regionxincountryy }}$ is the final $\mathrm{RIC}$ in a region of a given country, $\mathrm{CC}_{\text {countryy }}$ represents national average of the indicator CC (GM6) from the set of World Bank Governance Indicators (WGI), PC qogregionxincountry is the score from regional research of questions focused on corruption (pillar of corruption), $\mathrm{CPC}_{\text {qogcountryy }}$ is the average of regional research of all regions in a country weighted by the proportion of population of each region per national population of a given country.

The designed method was subsequently verified for the following use at national and sub-national levels as well. It was analysed the time series from 2008 to 2016 period. For mathematical verification, Kendall's coefficient of concordance is used. This is a non-parametric statistical method and is mainly 
used for the assessment of conformity of individual evaluators. Its value ranges between 0 (no agreement) and 1 (complete agreement) (Chraska, 2007).

Rankings of countries according to the RIC are compared with rankings of the existing indexes measuring the level of corruption at the national level. The selected indicators are Corruption Perception Index of Transparency International and the CC from the World Bank. Kendall's coefficient showed at least $95 \%$ level of consensus between the RIC and all selected indicators. For verification at the regional level, corruption offenses in Czech NUTS II regions, which are published statistics of the police of the Czech Republic, are used. The RIC is consistent with police statistics at least $40 \%$ level. The proposed index has been validated at both national and regional levels.

\section{The regional corruption variability within European countries}

The proposed RIC was applied to the cohesion regions of European countries. From the resulting values, the individual regions can be mutually compared and identified which regions are more or less affected by corruption.

Graphical models of RIC variability in 30 evaluated countries for years 2010, 2013 and 2016 were created using the program Statistica 12. Box plots use the method of min-max comparison and show the range of RIC values labelled the best and the worst evaluated NUTS II region. States are plotted on the $x$-axis, whereas RIC values are plotted on the $y$-axis. The range of RIC values is complemented by the final value of RIC of the country, which is represented by the star symbol.

Figure 2 shows the range of RIC 2010 values. The greatest variability reaches an assessment of corruption in Italian regions. The most corrupt Italian region is Campania (ITF3), whereas the best rating reached Umbria (ITE2). High variability was also found in Romania, France and Netherlands. Rating corruption at the national level can be very distorting for these countries.

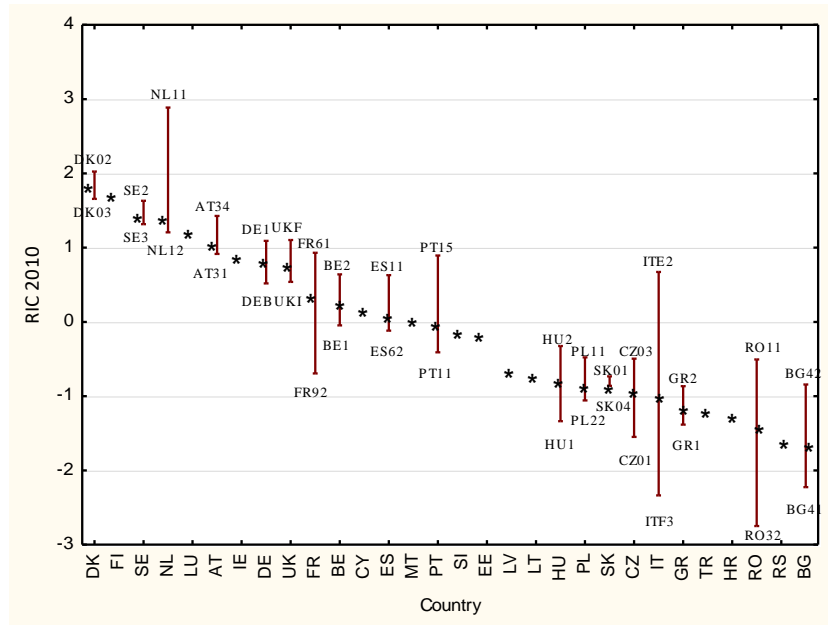

Figure 2. Regional variability of corruption 2010

Figure 3 shows the range of RIC 2013 values. The region with the lowest level of corruption was Finnish Aland (FI20) with a value of 2.3932. The most corrupt region was a Bulgarian Yugozapaden (BG41) with a value of -2.5237 .

A high variability of level of regional corruption was detected again in Italy, as well as Bulgaria, Turkey and Romania. The inhabitants of these countries have different opinions about the level of corruption in their regions, and the national corruption evaluation may not correspond with the actual situation in some regions. In contrast, in Danish, Swedish, Irish and Croatian regions were detected only very small deviations in the RIC 2013 values and evaluation of the national level of corruption relevantly reflects also the evaluation of individual NUTS II regions. 


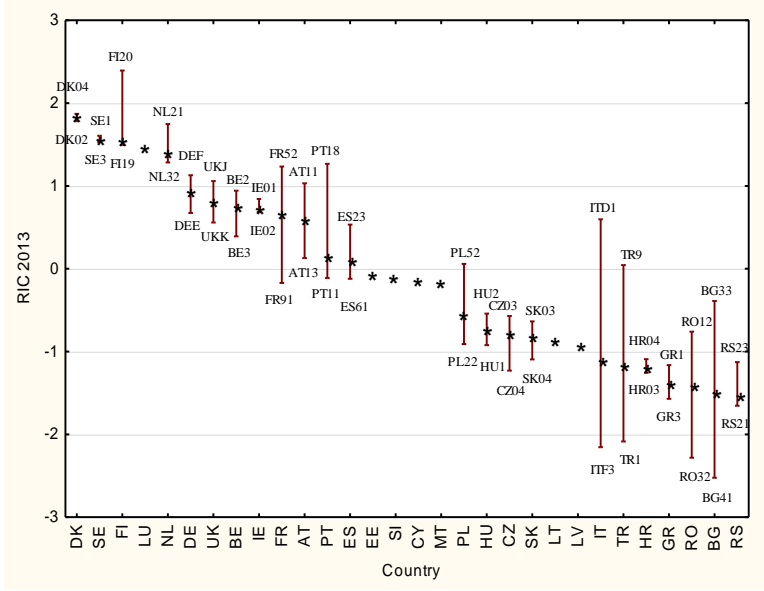

Figure 3. Regional variability of corruption 2013

The highest variability of regional corruption rate was found in Italian regions in both regional indexes of corruption. Italy, as one of the countries, has been written several studies focus on the topic of regional corruption. Del Monte and Papagni (2007) and Fiorino, Galli and Petrarca (2012) in their studies claim that the variability in the level of corruption in Italian regions is very variable. It is possible to find Italian regions with a very high level of corruption and regions with much lower levels of corruption as well. According to Fiorino et al. (2012), Campania and Sicilia are the most corrupt regions. Rating of RIC for the years 2010 and 2013 in principle agrees in the conclusions of these authors.

Using the control corruption indicator values for 2016, the RIC 2016 was created and it is shown in Figure 4. The extent of corruption in the regions remains unchanged, as it is based on the previous survey questionnaire. However, due to the World Bank's Control Corruption Indicator, the results of the RIC were updated. The box plot shows the rank of change of analysed countries. This is due to the rate of change of countries by the World Bank. For example, Denmark has slightly worsened its position. Finland, on the other hand, achieved a very positive rating in the Control Corruption Indicator 2016, which helped this Scandinavian country to rank first in the proposed RIC. The country with the highest level of corruption in 2016 is Romania, followed by Turkey and Bulgaria.

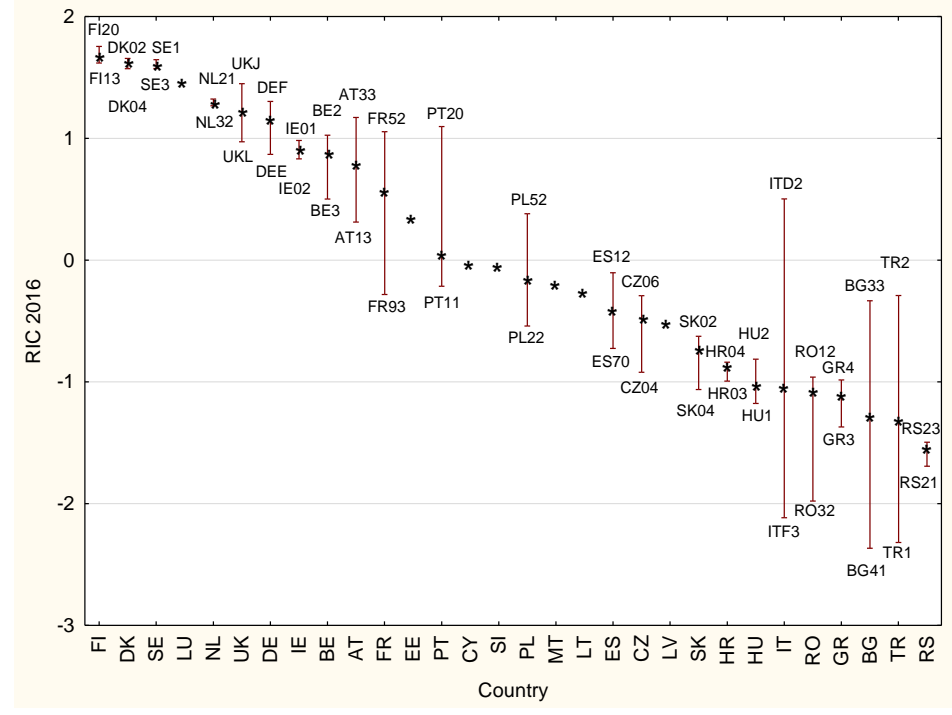

Figure 4. Regional variability of corruption 2016 
Table 1 shows the results of ranking of countries (NUTS I level) in the newly created RIC for the years 2010, 2013 and 2016. The higher the value of the RIC, the better is the evaluation of the country's RIC. In the evaluation of the RIC, it was found that the new Member States and candidate States of the European Union are at the very bottom of the list of countries evaluated. Conversely, the Nordic countries were evaluated as the least affected by corruption.

Table 1. RIC for 2010, 2013 and 2016

\begin{tabular}{|c|c|c|c|c|c|c|c|c|}
\hline NUTS I & RIC 2010 & Ranking & NUTS I & RIC 2013 & Ranking & NUTS I & RIC 2016 & Ranking \\
\hline $\begin{array}{l}\mathrm{DK} \\
\mathrm{FI}\end{array}$ & $\begin{array}{l}1.811919 \\
1.740486\end{array}$ & $\begin{array}{l}1 \\
2\end{array}$ & $\begin{array}{l}\text { DK } \\
\text { SE }\end{array}$ & $\begin{array}{l}1.841393 \\
1.559288\end{array}$ & $\begin{array}{l}1 \\
2\end{array}$ & $\begin{array}{l}\mathrm{FI} \\
\mathrm{DK}\end{array}$ & $\begin{array}{l}1.677508 \\
1.628438\end{array}$ & $\begin{array}{l}1 \\
2\end{array}$ \\
\hline SE & 1.516722 & 3 & $\mathrm{FI}$ & 1.555572 & 3 & SE & 1.601596 & 3 \\
\hline NL & 1.438868 & 4 & LU & 1.493145 & 4 & LU & 1.423362 & 4 \\
\hline LU & 1.261475 & 5 & $\mathrm{NL}$ & 1.479409 & 5 & $\mathrm{NL}$ & 1.269339 & 5 \\
\hline AT & 1.142543 & 6 & $\mathrm{DE}$ & 0.932501 & 6 & UK & 1.182688 & 6 \\
\hline IE & 0.948732 & 7 & UK & 0.779821 & 7 & $\mathrm{DE}$ & 1.116389 & 7 \\
\hline $\mathrm{DE}$ & 0.917613 & 8 & $\mathrm{BE}$ & 0.749709 & 8 & $\mathrm{IE}$ & 0.871916 & 8 \\
\hline UK & 0.830591 & 9 & $\mathrm{IE}$ & 0.726454 & 9 & $\mathrm{BE}$ & 0.842034 & 9 \\
\hline FR & 0.488344 & 10 & $F R$ & 0.703595 & 10 & AT & 0.769141 & 10 \\
\hline $\mathrm{BE}$ & 0.415918 & 11 & AT & 0.609217 & 11 & $F R$ & 0.550523 & 11 \\
\hline$C Y$ & 0.322032 & 12 & PT & 0.168304 & 12 & $\mathrm{EE}$ & 0.363279 & 12 \\
\hline ES & 0.157165 & 13 & ES & 0.131936 & 13 & PT & 0.051543 & 13 \\
\hline MT & 0.083101 & 14 & $\mathrm{EE}$ & -0.0212 & 14 & $\mathrm{CY}$ & -0.117806 & 14 \\
\hline PT & 0.029269 & 15 & SI & -0.05617 & 15 & SI & -0.143772 & 15 \\
\hline SI & -0.07815 & 16 & $\mathrm{CY}$ & -0.07266 & 16 & $\mathrm{PL}$ & -0.212298 & 16 \\
\hline $\mathrm{EE}$ & -0.12856 & 17 & MT & -0.1372 & 17 & MT & -0.246323 & 17 \\
\hline LV & -0.67118 & 18 & $\mathrm{PL}$ & -0.56423 & 18 & $\mathrm{LT}$ & -0.310540 & 18 \\
\hline LT & -0.70428 & 19 & $\mathrm{HU}$ & -0.76712 & 19 & ES & -0.484798 & 19 \\
\hline $\mathrm{HU}$ & -0.71697 & 20 & $\mathrm{CZ}$ & -0.7947 & 20 & $\mathrm{CZ}$ & -0.506607 & 20 \\
\hline $\mathrm{PL}$ & -0.76271 & 21 & SK & -0.85981 & 21 & LV & -0.524933 & 21 \\
\hline SK & -0.81496 & 22 & LT & -0.86415 & 22 & SK & -0.838563 & 22 \\
\hline $\mathrm{CZ}$ & -0.85541 & 23 & LV & -0.92744 & 23 & $\mathrm{HR}$ & -0.890095 & 23 \\
\hline IT & -0.87991 & 24 & IT & -1.05754 & 24 & $\mathrm{HU}$ & -1.028858 & 24 \\
\hline GR & -1.06275 & 25 & TR & -1.08985 & 25 & IT & -1.071623 & 25 \\
\hline TR & -1.08395 & 26 & $\mathrm{HR}$ & -1.14626 & 26 & RO & -1.129930 & 26 \\
\hline$H R$ & -1.23592 & 27 & $\mathrm{GR}$ & -1.38318 & 27 & $\mathrm{GR}$ & -1.192931 & 27 \\
\hline RO & -1.37328 & 28 & RO & -1.39001 & 28 & $B G$ & -1.327005 & 28 \\
\hline RS & -1.55004 & 29 & BG & -1.43259 & 29 & TR & -1.370090 & 29 \\
\hline BG & -1.55089 & 30 & RS & -1.46287 & 30 & RS & -1.509819 & 30 \\
\hline
\end{tabular}

The country that most improved its ranking between years 2010 and 2016 is Poland. From the 21st position in 2010, Poland got the 16th position in the RIC 2016. This means an improvement of a total of five positions during the analysed period. Better evaluation of corruption might be related to the de-politicisation of the corruption topic in Poland. The current PO administration ('Platforma Obywatelska' or Civic Platform) claims that its implementation of the anti-corruption strategy goes well despite some delays. It would appear that the Polish authorities take the issue of corruption prevention in respect of Members of Parliament, judges and prosecutors seriously and should be commended for this. On the other hand, Spain was the biggest slump, falling from its 13th position to 19th position, therefore six bars in the ranking.

\section{Conclusion}

There has been no method to quantify the phenomenon of corruption at the regional level until nowadays. If corruption is one of the variables that are degrading the economic performance, as many 
studies claim, just the elimination of corruption in certain regions may be the key for the elimination of regional economic disparities and thus increase the economic performance of the state. The European Commission highlights the corruption increasing activity in some NUTS II regions in connection with the misuse of European funds. These sources often do not paradoxically help remove unwanted regional disparities, but the distribution of those resources demonstrably increases opportunities for corruption. This, in turn, gives additional negative economic consequences to the region, which may lead to an increase of disparities within the state.

The goal of regional politics is to sustain positive disparities and restrain or eventually completely remove the negative ones. From the viewpoint of corruption rate, the sub-national distinction of regions of aggregation would pose a completely new extension of the theory of reasons and consequences of regional disparities. The possibility of defining regions more affected by corruption would allow concentrating tools of anti-corruption politics mainly on regions which are mostly affected by corruption and this would create a new tool for the elimination of regional disparities. Diversification of individual regions of aggregation would also pose valuable benefit for the current anti-corrupt politics of a country. Individual tools of anti-corruption politics could be so focused mainly on spheres which will be evaluated as the most problematic ones. Regarding the extent and diversity of questions of questionnaire investigation created by the European Commission, it will be also possible to evaluate which sphere of public services was evaluated by respondents as the most problematic one. This will also allow focusing anti-corruption activities on concrete spheres of public services and increase the probability of efficiency of these arrangements.

\section{References}

Del Monte, A. \& Papagni, E. (2007). The determinants of corruption in Italy: Regional panel data analysis. European Journal of Political Economy, 23(2), 379-396.

European Commission. (2011). Anti-corruption report 2014. Retrieved from http://ec.europa.eu/dgs/homeaffairs/what-we-do/policies/organized-crime-and-human-trafficking/corruption/anti-corruptionreport/index_en.htm

European Commission. Measuring Quality of Government and Sub-National Variation. Regional Policy. Retrieved from http://ec.europa.eu/regional_policy/sources/docgener/studies/pdf/2010_government_1.pdf

Fiorino, N., Galli, E. \& Petrarca, I. (2012). Corruption and growth: evidence from the Italian regions. European Journal of Government and Economics, 1(2), 126-144.

Golden, M. A. \& Picci, L. (2005). Proposal for a new measure of corruption, illustrated with Italian data. Economics \& Politics, 17(1), 37-75.

Huntington, S. P. (2006). Political order in changing societies. London, UK: Yale University Press.

Jain, A. K. (2001). Corruption: a review. Journal of economic surveys, 15(1), 71-121.

Kim, C. K. (2007). A cross-national analysis of global E-government. Public Organization Review, 7(4), 317-329.

Kimbro, M. B. (2002). A cross-country empirical investigation of corruption and its relationship to economic, cultural, and monitoring institutions: an examination of the role of accounting and financial statements quality. Journal of Accounting, Auditing \& Finance, 17(4), 325-350.

Leff, N. H. (1964). Economic development through bureaucratic corruption. American Behavioral Scientist, 8(3), 8-14.

Leff, N. H. (1989). Economic development through bureaucratic corruption. In A. J. Heidenheimer, M. Johnston \& V. T. LeVine (Eds.), Political corruption: a Handbook. New Brunswick NJ: Transaction Books, pp 389-403.

Mauro, P. (1998). Corruption and the composition of government expenditure. Journal of Public economics, 69(2), 263-279.

Mauro, P. (2004). The persistence of corruption and slow economic growth. IMF Staff Papers, 51(1), 1-18.

Meon, P. G. \& Weill, L. (2010). Is corruption an efficient grease? World Development, 38(3), 244-259.

Mo, P. H. (2001). Corruption and economic growth. Journal of Comparative Economics, 29(1), 66-79.

Myrdal, G. (1972). Asian drama; an inquiry into the poverty of nations (Vol. 1). New York, NY: Pantheon Books. 
Nye, J. S. (1967). Corruption and political development: a cost-benefit analysis. American Political Science Review, 61(2), 417-427.

Rose-Ackerman, S. (1997). The political economy of corruption. Corruption and the Global Economy, 31, 60.

Shleifer, A. \& Vishny, R. W. (1993). Corruption. The Quarterly Journal of Economics, 108(3), 599-617.

Tanzi, V. (1998). Corruption around the world: causes, consequences, scope, and cures. Staff Papers, 45(4), 559-594.

The Quality of Government Institute. (2013). From Aland to Ankara: European Quality of Government index. Gothenburg, Sweden: University of Gothenburg. Retrieved from http://www.qog.pol.gu.se/ digitalAssets/1455/1455551_2013_11_charron.pdf 